\title{
Landslide susceptibility analysis of Yamaç Basin in Bingol through the index method
}

\author{
Alaaddin YÜKSEL ${ }^{1}$, Vedat AVCi ${ }^{2 *}$ \\ ${ }^{1}$ Bingöl University, Department of Soil Science and Plant Nutrition, Bingöl, 12100, Turkey \\ ${ }^{2}$ Bingöl University, Department of Geography, Bingöl, 12100, Turkey \\ "Corresponding author: vavci@bingol.edu.tr
}

Received Date:27.04.2017

Accepted Date: 15.08 .2017

Abstract

Aim of study: The present study aims to analyze the landslide susceptibility of Yamaç Basin by applying the index method.

Area of study: Covering an area of $78 \mathrm{~km}^{2}$, Yamaç Basin is located in the southern part of Bingöl Province. The basin is composed of lithological agglomerate, tuff, conglomerate and sandstone. The difference in elevation between the northern and southern part of the basin reaches as high as $1000.00 \mathrm{~m}$. Heavy precipitation, sparse vegetation, and high levels of river density have been observed in the basin.

Material and Methods: In this study landslide susceptibility of Yamaç Basin was analyzed by using the parameters of lithology, slope, aspect, normalized difference vegetation index (NDVI), distance to river systems and curvature.

Main results: According to the susceptibility map based on the index method, landslide susceptibility is very high in northern, western and northwestern parts of the basin where a land route stretches from Yamaç to Olukpınar Village.

Research highlights: Natural and environmental factors were not evaluated during either the construction of the first settlement or of the first road. Thus, landslides cost significant economic losses every year. Therefore, it is urgently necessary to carry out studies on basin-scale planning in order to cope with the damages and problems caused by landslides.

Keywords: Yamaç Basin, Bingöl, Landslide, Index Method, Environment.

\section{İndeks metodu ile Yamaç Havzası’nın (Bingöl) heyelan duyarlılık}

\section{analizi}

Özet

Çalışmanın Amacı: Bu çalışmada İndeks Metodu kullanılarak Yamaç Havzası için heyelan duyarlılık analizlerinin yapılması amaçlanmıştır.

Çalışma Alanı: Yamaç Havzası, Bingöl'ün güneyinde yer almakta olup, $78 \mathrm{~km} 2$ alan kaplamaktadır. Kuzeyi ile güneyi arasında yükselti farkının 1000 m'yi bulduğu havzada litoloji aglomera, tüf, konglomera ve kumtaşından oluşmaktadır. Yağış miktarının fazla olduğu inceleme alanında, bitki örtüsü seyrek olup, akarsu yoğunluğu yüksektir. Doğal koşulların elverişli olması nedeniyle meydana gelen heyelanlar önemli ekonomik kayıplara yol açmaktadır.

Materyal ve Yöntem: Bu çalışmada litoloji, eğim, bakı, Normalize Fark Bitki İndeksi (NDVI), akarsu ağlarına uzaklık ve yamaç eğriselliği parametreleri kullanılarak Yamaç Havzası için heyelan duyarlılık analizleri yapılmıştır. İndeks metodu kullanılarak oluşturulan duyarlılık haritasına göre havzanın kuzeyi, kuzeybatısı ve batısında heyelan duyarlılığı oldukça yüksek olup, Yamaç ve Olukpınar köyleri arasında karayolu duyarlılığın yüksek olduğu alandan geçirilmiştir.

Araştırma vurgularl: Yörede yerleşmeler kurulurken ve yollar yapılırken doğal çevre koşulları dikkate alınmamıştır. Bu nedenle heyelanlar her yıl önemli ekonomik kayıplara neden olmaktadır. Heyelanların meydana getireceği sorunları azaltmak için havza ölçeğinde planlama çalışmalarının hızlandırılması gerekmektedir.

Anahtar Kelimeler: Yamaç Havzası, Bingöl, Heyelan, İndeks Metodu, Doğal Çevre 


\section{Introduction}

Landslide is a natural disaster which occurs frequently in the mountainous region of the world and causes loss of life and property. According to the Centre for Research on the Epidemiology of Disasters (CRED), landslide ranked 5th in terms of number of deaths is among the top ten most important disasters in 2010 (OFDA/CRED, 2010).

Geologic, geomorphologic, meteorological, environmental and humanrelated factors contribute to the occurrence of landslide as the preparatory and triggering factors. Landslides are regarded as one of the greatest risk factors for the environment as well as human economical activities (Caniani et al, 2008).

Due to the lack of information about when landslides generally occur and the main contributing causes of landslides, landslide analyses tend to concentrate on landslide susceptibility studies (Ermini et al, 2005). Generated susceptibility maps allow one to determine when an area is prone to landslides or has the potential to become a landslide zone.

Determination of would-be landslides or the area having the potential to become a landslide zone through susceptibility analyses is executed by using past land susceptibilities - thus, the combination of between-spatial distributions leading to slope susceptibility characteristics and past landslide distributions (Carrara et al, 1991). Several methods are used to study the risks caused by ground motion. The methods are divided into two types: qualitative and quantitative. The qualitative methods are executed through geomorphological observations and evaluations in the field by generating index maps; thus, predictions can be made using previous knowledge and ground motion that has already occurred. The quantitative methods are rather composed of statistical analyses, geotechnical approaches, artificial neural nets and fuzzy logical approaches calculated with the help of laboratory studies and mathematical equations. Distribution, quantitative, statistical, deterministic and frequency analyses are widely used in landslide susceptibility studies (Carrara et al, 1991; Van Westen, 1993; Ermini et al, 2005).

Susceptibility analyses for Yamaç Basin were done using the index method from statistical analysis methods. This approach, based on the Geographic Information System (GIS), is one of the most effective methods used for the spatial planning method. These analyses can be used in environmental planning, ecological management, urban and regional planning, hydrology and water resources, and forestry and transportation, as well as in agriculture, natural hazard method, and allocation of health investment during decision and management steps.

Index method is outlined and considered by many as the simplest and quantitatively suitable method in susceptibility mapping (Yin \& Yan 1988; Wu et al, 2001; Zezere, 2002; Cevik \& Topal, 2003; Saha et al, 2005; Yalçın, 2008; Bui et al, 2011; Pourghasemi et al, 2013; Regmi et al, 2014; Bourenane et al. 2015; Chen et al, 2016). This approach is based on the observed relationships between each predisposing factor and the distribution of landslide areas. The weighting value for each class is defined as the natural logarithm of the landslide density in a class divided by the landslide density in the whole studied area (Van Westen, 1997).

Before creating the susceptibility maps, landslide areas were digitalized and then transformed to a raster format. The parameter maps were classified in order to superpose with the landslide maps. The landslide map transformed to a raster format was superposed with the factor maps which already reclassified through Spatial AnalysisCombine Module (ArcGIS v. 10.1), thus, pixel numbers of the sub-class parameters in the landslide and of sub-class parameters themselves were calculated. The landslide density was then obtained through MS Excel by using the calculated values. The landslide density parameter was combined with the maps and collected in Raster Calculator Module (ArcGIS v. 10.1). 
Material and Method

Field of Study and its Specifications

Yamaç Basin is located in the southern part of Bingol Province and covers an area of
$78 \mathrm{~km} 2$. The stream of the basin encircling Karaömer Mountain in the north joins the Murat River in the south (Fig. 1).

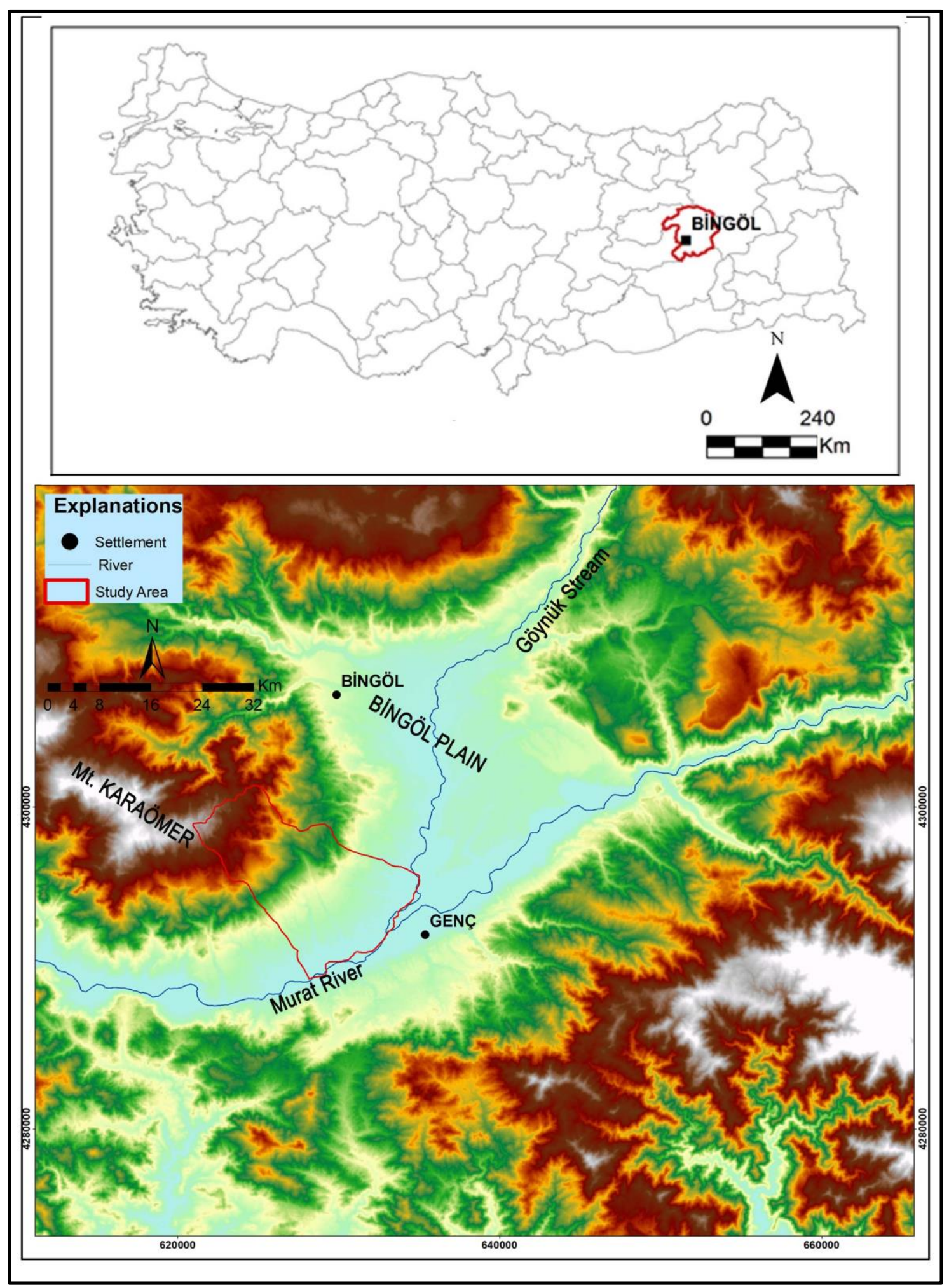

Figure 1. Location of Yamaç Basin 
Mount Karaömer (2373 m) in the northern part of the basin has a young and excessively cracked topography. The Upper MiocenePliocene developed over older Solhan volcanic rocks. However, the morphology has attained different structures shaped during the neotectonic area (Middle-Upper Miocene). The lithology of Mount Karaömer is composed of a folded structure formed by intercalated tuffs and lava (Tonbul, 1990a). The elevation difference between the southern and northern parts of Yamaç Basin is almost $1000 \mathrm{~m}$. Natural vegetation characterized by types of steppe and forests has been severely damaged in the basin. The lithology consists of agglomerate, tuff, conglomerate and sandstone. Alluvial deposits are dominant in the south, where the valley of the Murat River expands.

Landslides have been observed most commonly on the Upper Miocene-Pliocene formed of old tuffs. The tuffs contain high amount of clay, which contributed to the landslide events. Depending on the clay structure, the wide-field landslides occur when the rainfall and snowmelt increase. Landslides occur less commonly in the south of the Yamaç basin where the lithology formed of alluvial rocks.

The basin faces air masses from the southwest, and thus, the high areas facing backward in the north of the basin receive much of the precipitation (Fig 2).

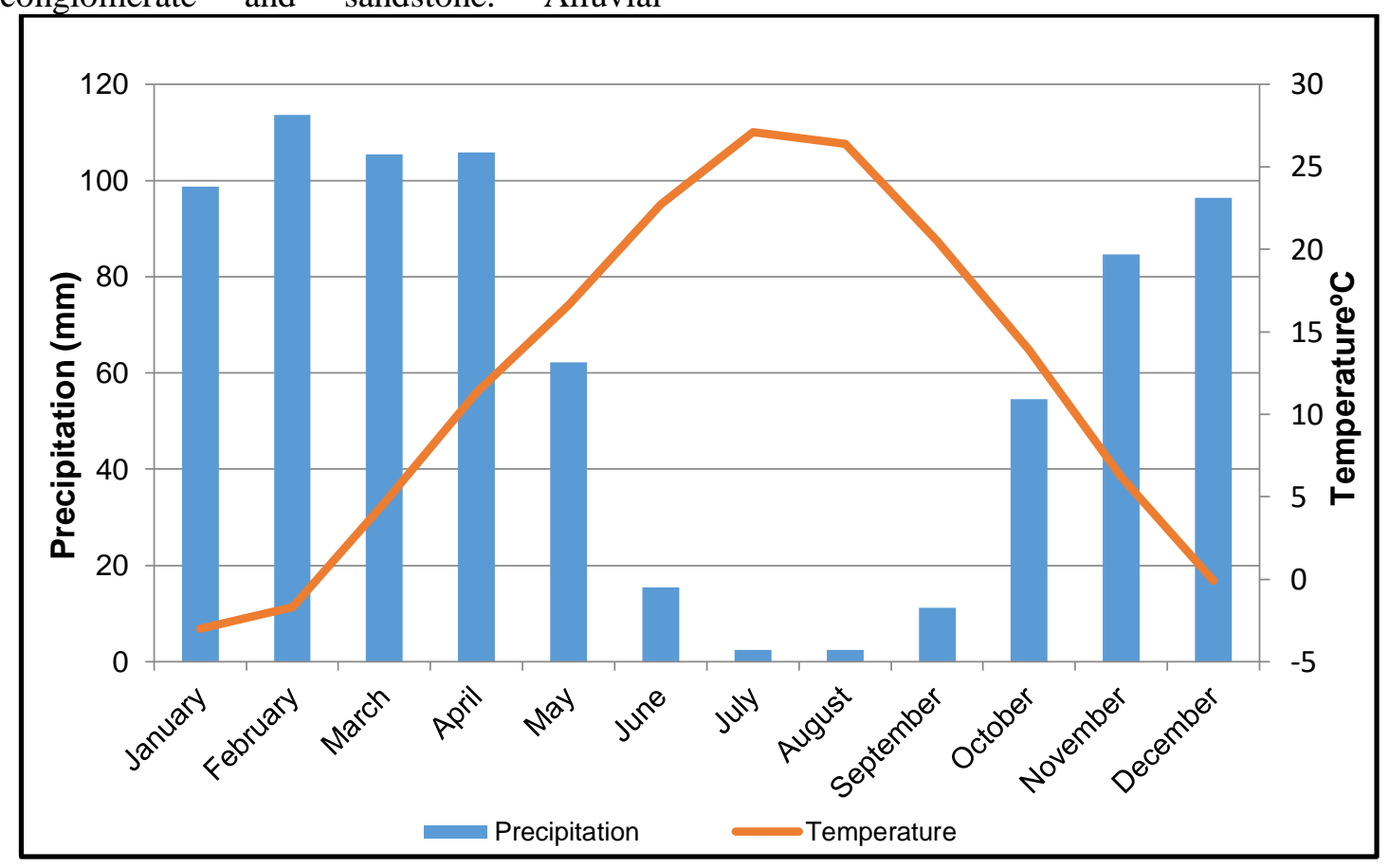

Figure 2. Long-term (1975-2013) average monthly temperature and precipitation in Yamaç Basin (Genç, Bingöl)

NDVI values indicate the majority of the basin does not have vegetation cover. Areas where the drainage density is $0-5 \mathrm{~km} 2$ cover much of the basin, and areas that are at $100-250 \mathrm{~m}$ distance from the river cover more than $50 \%$ of the basin. The landslides in Yamaç Basin cover an area of $5 \mathrm{~km} 2$ and spread between Yamaç and Olukpınar villages. The landslide inventory map was obtained using the field works and the Erzurum plot from the inventory map of the Mineral Research and Exploration Institute
(Fig. 3). Landslides are classified as slide, earth flows and falls. Earth flows occur in slopes where the fine-grained ground materials become saturated with enough water and, thus, completely unconsolidated. Dry earth flows are very rare. When rivers erode and undermine the base of a slope, this leads to a fall-type landslide. Landslides observed in the basin are generally of slide type. For this reason, other types of landslides have been mapped in this group. 


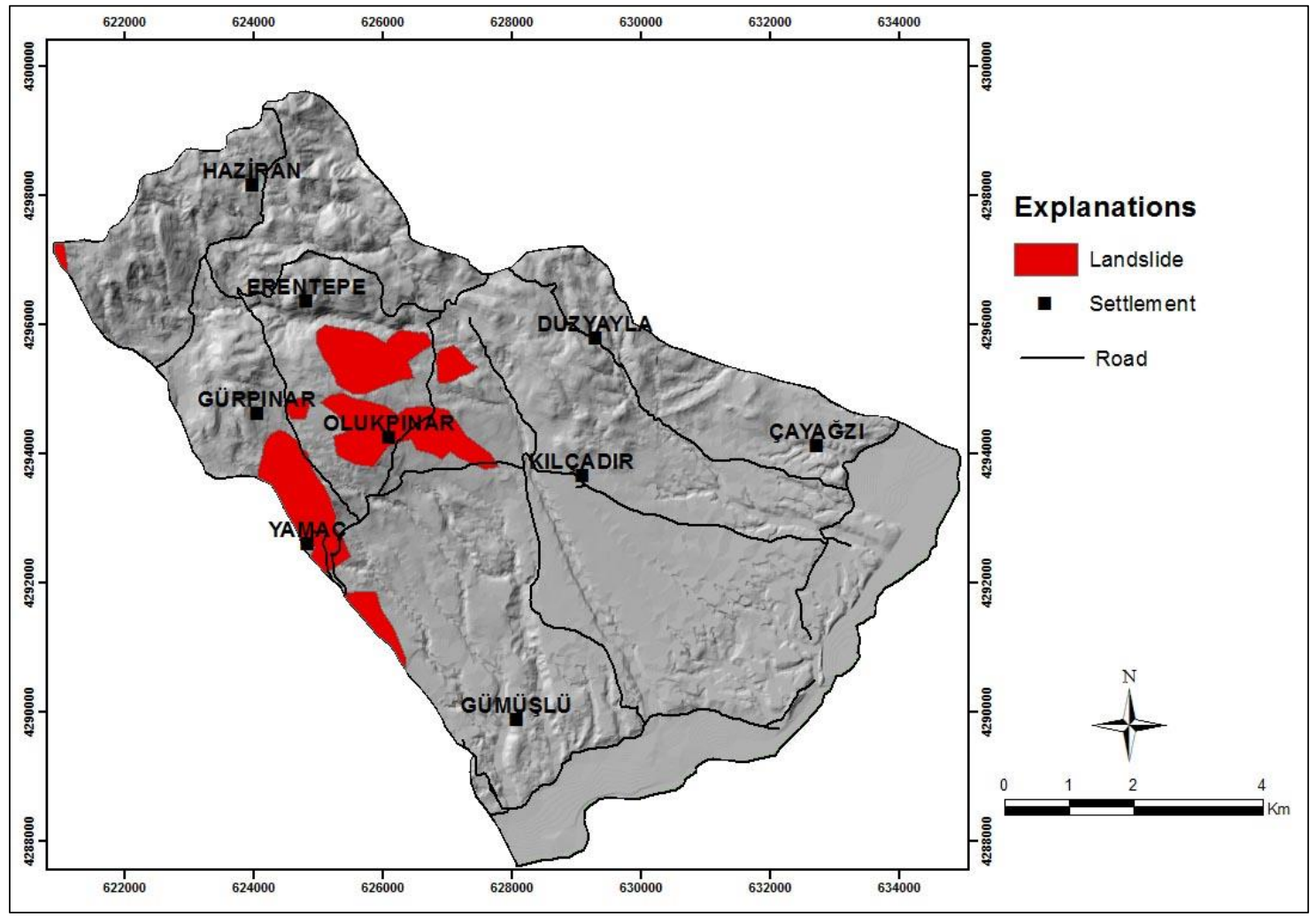

Figure 3. Distribution of Landslides in Yamaç Basin in Bingö1

\section{Index Method}

The proper parameters need to be chosen in order to apply statistical methods successfully in landslide susceptibility analysis. The geological structure of the territory, proximity to major faults, slope, drainage network, elevation, shape and aspect of the slope, vegetation, density of road and seismicity are taken into consideration when a susceptibility analysis is performed (Guzzetti et al, 1999; Dai et al, 2001; Chi et al, 2002; Saha et al, 2002; Lee et al, 2004; Yalçın, 2007).

Lithology, slope, aspect, NDVI, distance to networks of rivers and parameters of slope curvature have been used in this study. Studies on active landslide areas and the
Inventory of The General Management of the Mineral Research Analysis (MRA) Institute have been digitized using Erzurum thread. The digital elevation model (DEM) has been obtained by digitizing the topographic maps. Slope, aspect and curvature maps have been obtained from DEM. The lithology of the study area has been acquired from geology map, and distance from the river network map has been obtained from topographic maps. NDVI values have been gathered from Landsat satellite images. Range, quantitative, statistical, determinist and frequency analyses are widely used in landslide susceptibility (Table 1). 
Table 1. Common approaches to damage and susceptibility analyses for landslides (Van Westen, 1993).

\begin{tabular}{cl}
\hline Analysis Type of Susceptibility & Basic Features \\
\hline Analysis of Range & Information in the form of a map about past landslide(s) and erosion \\
\hline Quantitative Analysis & $\begin{array}{l}\text { Method of combining many maps based on a user's experience, } \\
\text { adopting a direct and semidirect approach }\end{array}$ \\
\hline Statistical Analysis & $\begin{array}{l}\text { Indirect methods that use a series of parameter maps and statistical } \\
\text { methods to find possibility values }\end{array}$ \\
\hline Deterministic Analysis & $\begin{array}{l}\text { Indirect methods that combine parameter maps, including results of } \\
\text { stability analyses }\end{array}$ \\
\hline Frequency Analysis & $\begin{array}{l}\text { Uses the correlations of known locations, earthquake events and } \\
\text { precipitation to obtain the limit value in a certain frequency }\end{array}$ \\
\hline
\end{tabular}

The index method, which is one of the bivariate statistical analyses, is used for susceptibility analyses. The core of this method is composed of superposed parameters selected for susceptibility and landslide density calculation. Each parameter is individually evaluated. Then, a map of the landslide density is formed by collecting weight values issued to these parameters (Van Westen, 1993). The index method is based on the density inside each parameter selected to identify the landslide density of the existing landslides. The entire association of the study area was accomplished to standardize the density of the parameters. The weight value of landslide susceptibility of the subclasses in each parameter is calculated by the natural logarithm of dividing the subclasses' landslide density by the landslide density of the whole area (Van Westen, 1997). It is possible to apply in a GIS setting with the following formula:

$$
W i=\ln \frac{\text { Densclas }}{\text { Densmap }}=\ln \left[\frac{\frac{\operatorname{Npix}\left(S_{i}\right)}{\operatorname{Npix}\left(N_{i}\right)}}{\frac{\sum \operatorname{Npix}\left(S_{i}\right)}{\sum \operatorname{Npix}\left(N_{i}\right)}}\right]
$$

In this formula;

Wi: Weight value of subclasses of parameters

Densclas: Landslide density of subclasses

Densmap: Landslide density of the whole area Npix (Si): Pixel numbers of landslide of parameter's subclasses

Npix (Ni): Pixel numbers of parameters' subclasses

Parameters and values to be used in the susceptibility map using Arcgis 10.1 Program Spatial Analysis Module are shown in Table 2. 
Table 2. Parameters and Weight Values used in Landslide Susceptibility Map

\begin{tabular}{|c|c|c|c|c|c|c|c|c|}
\hline Layers & & $\begin{array}{l}\text { Pixel for } \\
\text { landslide } \\
\text { of sub- } \\
\text { classes }\end{array}$ & $\begin{array}{l}\text { Pixel } \\
\text { for sub- } \\
\text { classes }\end{array}$ & $\begin{array}{l}\text { Landslide } \\
\text { density in } \\
\text { sub-classes }\end{array}$ & $\begin{array}{l}\text { Total pixel } \\
\text { for } \\
\text { landslides }\end{array}$ & $\begin{array}{l}\text { Pixel for } \\
\text { the } \\
\text { whole } \\
\text { area }\end{array}$ & $\begin{array}{l}\text { Landslide } \\
\text { density in } \\
\text { the whole } \\
\text { area }\end{array}$ & $\begin{array}{l}\text { İndex } \\
\text { Method } \\
W i\end{array}$ \\
\hline \multirow{3}{*}{ Lithology } & $\begin{array}{l}\text { Agglomerate, } \\
\text { Tuff }\end{array}$ & 42498 & 355005 & 0,119711 & 50762 & 786636 & 0,06453 & 0,268369 \\
\hline & Alluvion & 0 & 95827 & 0 & 50762 & 786636 & 0,06453 & 0 \\
\hline & $\begin{array}{l}\text { Conglomerate, } \\
\text { Sandstone }\end{array}$ & 8264 & 335804 & 0,02461 & 50762 & 786636 & 0,06453 & $-0,41866$ \\
\hline \multirow{5}{*}{ Slope (o) } & $0-7$ & 4099 & 267270 & 0,015337 & 50762 & 786636 & 0,06453 & $-0,62404$ \\
\hline & $7-15$ & 28136 & 239558 & 0,11745 & 50762 & 786636 & 0,06453 & 0,260087 \\
\hline & $15-25$ & 15036 & 176922 & 0,084987 & 50762 & 786636 & 0,06453 & 0,119586 \\
\hline & $25-35$ & 3477 & 99970 & 0,03478 & 50762 & 786636 & 0,06453 & $-0,26843$ \\
\hline & $35-53$ & 14 & 2916 & 0,004801 & 50762 & 786636 & 0,06453 & $-1,12842$ \\
\hline \multirow{9}{*}{ Aspect } & Flat & 1344 & 113803 & 0,01181 & 50762 & 786636 & 0,06453 & $-0,73752$ \\
\hline & North & 1387 & 28318 & 0,048979 & 50762 & 786636 & 0,06453 & $-0,11975$ \\
\hline & Northeast & 209 & 82231 & 0,002542 & 50762 & 786636 & 0,06453 & $-1,40465$ \\
\hline & East & 404 & 136826 & 0,002953 & 50762 & 786636 & 0,06453 & $-1,33955$ \\
\hline & Southeast & 6998 & 194164 & 0,036042 & 50762 & 786636 & 0,06453 & $-0,25296$ \\
\hline & South & 11564 & 124238 & 0,093079 & 50762 & 786636 & 0,06453 & 0,159089 \\
\hline & Southwest & 2043 & 74264 & 0,02751 & 50762 & 786636 & 0,06453 & $-0,37027$ \\
\hline & West & 18590 & 22184 & 0,837991 & 50762 & 786636 & 0,06453 & 1,113475 \\
\hline & Northwest & 8223 & 10608 & 0,77517 & 50762 & 786636 & 0,06453 & 1,079632 \\
\hline \multirow{5}{*}{ NDVI } & $-0,6-0$ & 46700 & 667224 & 0,069991 & 50762 & 786636 & 0,06453 & 0,03528 \\
\hline & $0-0,1$ & 3195 & 70497 & 0,045321 & 50762 & 786636 & 0,06453 & $-0,15346$ \\
\hline & $0,1-0,2$ & 781 & 29016 & 0,026916 & 50762 & 786636 & 0,06453 & $-0,37975$ \\
\hline & $0,2-0,4$ & 80 & 16677 & 0,004797 & 50762 & 786636 & 0,06453 & $-1,12879$ \\
\hline & $0,4-0,58$ & 6 & 3222 & 0,001862 & 50762 & 786636 & 0,06453 & $-1,53974$ \\
\hline \multirow{6}{*}{$\begin{array}{c}\text { Distance } \\
\text { from River } \\
\text { Systems (m) }\end{array}$} & $0-100$ & 17113 & 333113 & 0,051373 & 50762 & 786636 & 0,06453 & $-0,09903$ \\
\hline & $100-250$ & 12268 & 267918 & 0,04579 & 50762 & 786636 & 0,06453 & $-0,14899$ \\
\hline & $250-500$ & 18995 & 129474 & 0,146709 & 50762 & 786636 & 0,06453 & 0,356692 \\
\hline & $500-750$ & 2386 & 32439 & 0,073553 & 50762 & 786636 & 0,06453 & 0,056838 \\
\hline & $750-100$ & 0 & 13730 & 0 & 50762 & 786636 & 0,06453 & 0 \\
\hline & $1000>$ & 0 & 9964 & 0 & 50762 & 786636 & 0,06453 & 0 \\
\hline \multirow{3}{*}{ Curvature } & Concave & 15423 & 249867 & 0,061725 & 50762 & 786636 & 0,06453 & $-0,0193$ \\
\hline & Plain & 17425 & 279837 & 0,062268 & 50762 & 786636 & 0,06453 & $-0,0155$ \\
\hline & Convex & 17914 & 256932 & 0,069723 & 50762 & 786636 & 0,06453 & 0,033609 \\
\hline
\end{tabular}

\section{Results and Discussion}

The Effect of Lithological Units on Landslide

Lithological units of different structural features have different susceptibilities for such active geomorphological processes as landslide and earthflow (Carrara et al, 1991). In Yamaç

Basin, the lithology consists of agglomerate, tuff, conglomerate, sandstone and alluvium. In the basin, which is predominantly covered with tuffs and agglomerates that have been formed as a result of Solhan Vulcanites, the lithology is composed of igneous rocks on the deep level and marl on the surface (Figure 4). The thickness of the unit in the region is between
20 and $30 \mathrm{~m}$ (Sümengen, 2011). The conglomerate and sandstone in the region are members of the Palu Formation. The unit composed of fans and river sediment has been named by Kerey \& Türkmen (1991). Pebble, sand and mud deposits in stream beds and depression areas belong to the Quaternary Period (Sümengen, 2011). The rocks in the north are permeable on the surface but impermeable on the base, which causes landslides by increasing the level of groundwater. Agglomerate and tuffs both formed of Solhan's volcanites are widely located on the surface of the Yamaç basin. The tuffs are rich in clay, which allows the tuffs to reach the plasticide limit easily. This event may trigger landslide occurrences. 


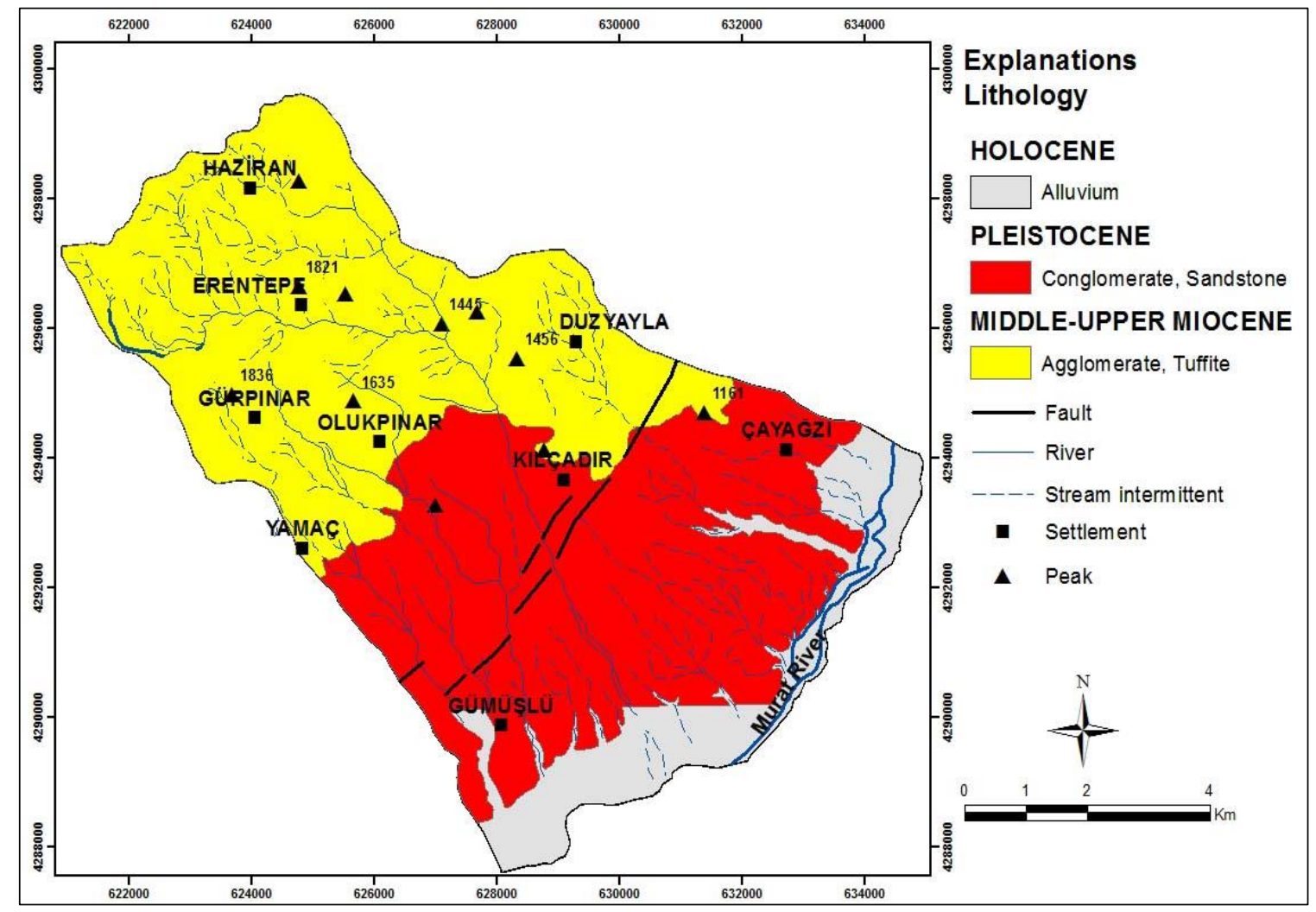

Figure 4. Geological map of Yamaç Basin (Bingöl)

\section{The Effect of Slope on Landslide}

Slope is the most important topographic parameter in the formation of landslides. The risk of landslide increases in places where the rate of slope is high. Many researchers such as (Dai et al, 2002, Gómez \& Kavzoglu 2005, Yalçın et al, 2011) have used the slope factor when forming susceptibility maps. Slope rates from DEM were measured in degrees and classified into five groups: $0-7$, $7-15,15-25,25-35$ and $35-53$. The slope rates change between 0 and $53^{\circ}$, and the average slope is $14^{\circ}$. The fields-the slope rates of which are between 15 and $25^{\circ}-$ cover wide areas. Slope rates are higher in the northern part of the catchment area. The fault area in the E-W direction of the catchment basin has caused an increase in slope rates in the north and the grading of land. The slope rates of terrace alluvial cones in the south are low. The slope rates change between 0 and $7^{\circ}$ (Fig. 5). 


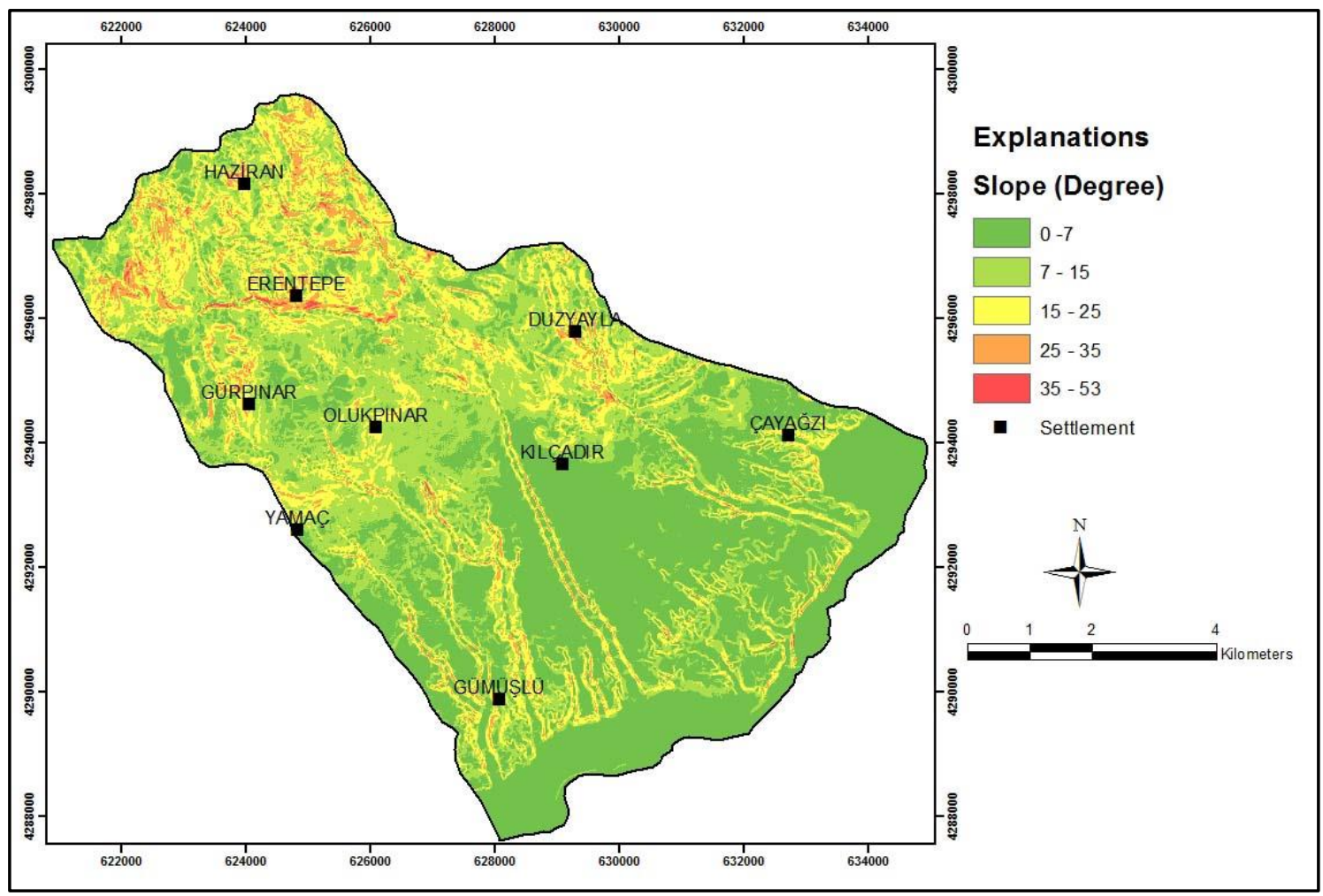

Figure 5. Slope map of Yamaç Basin (Bingöl)

Landslides become frequent in areas with slopes from 7 to $15^{\circ}$ and 15 to $25^{\circ}$. Landslides occur in these slope groups. Slopes with clay mold are rich in water content; therefore, wide field slides occur (Fig. 6).

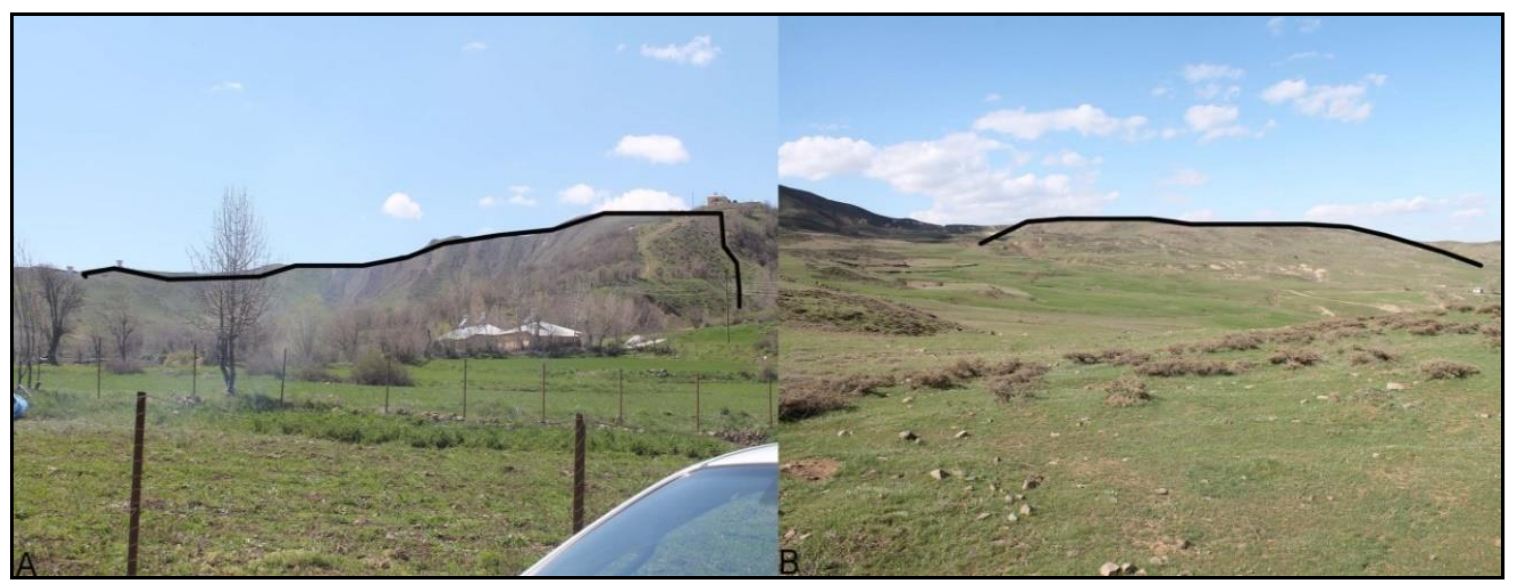

Figure 6. Landslides seen north of Yamaç Village

Occurrence of landslides in the groups of $7-15^{\circ}$ and $1-25^{\circ}$ more common compared to the others results in slower runoff. This slower runoff causes an increase in percolation. The increase in percolation creates landslides by rising the amount of underground water and weight of the layers. Seismic activate also has an effect on landslides seen on the lower angled slopes. From time to time, earthquakes occurring on the lower angled slopes may also cause landslides as well. 


\section{Effect of Aspect on Landslides}

Landslides become frequent on slopes (Baeza \& Corominas, 2001; Donati \& Turrini, 2002; Ayalew et al, 2004). Meteorological events especially general precipitation aspects of areas, general morphological features of fields, and increased sunlight have influence on intensifying slopes with definite tendencies. Slopes receiving heavy rain become saturated earlier than less-rainy slopes for various reasons (e.g., topographical incline, type of ground, permeability, porosity, content of moisture and organic material, vegetation cover and the season in which the rain occurs). Pore water pressures in the ground make this type of slope more susceptible to landslides. Therefore, slopes that get heavy rain are identified as more susceptible in the use of slope direction parameters (Ayalew \& Yamagishi, 2005). Slopes with southeast, southwest and south directions cover wide fields, according to the aspect map from the digital elevation model (Fig. 7, Table 2).

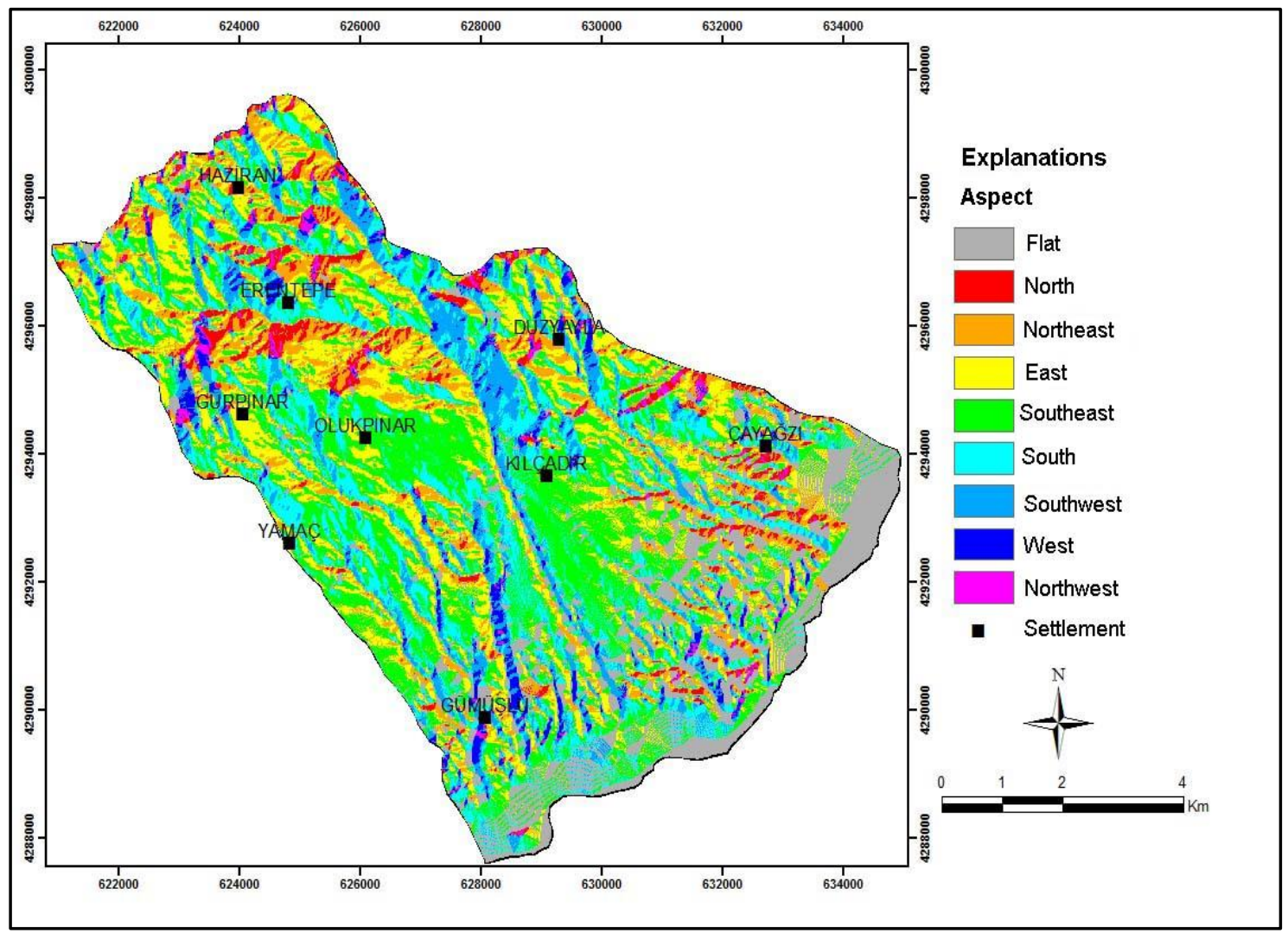

Figure 7. The aspect map of Yamaç Basin (Bingöl)

Bingöl and its surroundings face the moist air masses coming from the southeast, that is, the most rainy depression in the East Anatolia Region (Tonbul, 1990b). Being east, the direction of slopes causes the increase in precipitation. This leads to a significant difference between the precipitation of the northern and southern parts of the basin. As a result, landslides occur prevalently in the north, depending on the increment of precipitation. The snowmelt also contribute to the landslides occurring most commonly on the south-facing slopes of the basin. Fast snow melting due to higher temperature on these slopes enables occurrences of landslides. 
The Effect of Vegetation on Landslides

Vegetation is a factor that plays an important role in controlling landslides and helping the stabilization of slope factor through preserving the mechanical resistance of soil. According to the NDVI map formed for the basin, the fields deprived of vegetation cover a wide area. The stream basins correspond to the areas in which the vegetation is dense (Fig. 8). Almost all of the landslides seen in Yamaç Basin have occurred on the zones within which the NDVI values are between -0.6 and 0 . The cause of the landslides occurred in nonvegetative areas is due to the lack of the protective cover of the soil. For this reason, in order to reduce the damage caused by landslides in the basin, afforestation should be accelerated.

Between 2000 and 2012, significant changes in vegetation cover the area. When Coordination of Information on the Environment (Corine) data for these periods are examined, it is seen that the proportion of broad-leaved forests that cover $8.4 \%$ in 2000 falls to $3.6 \%$ in 2012 (Figure 9).

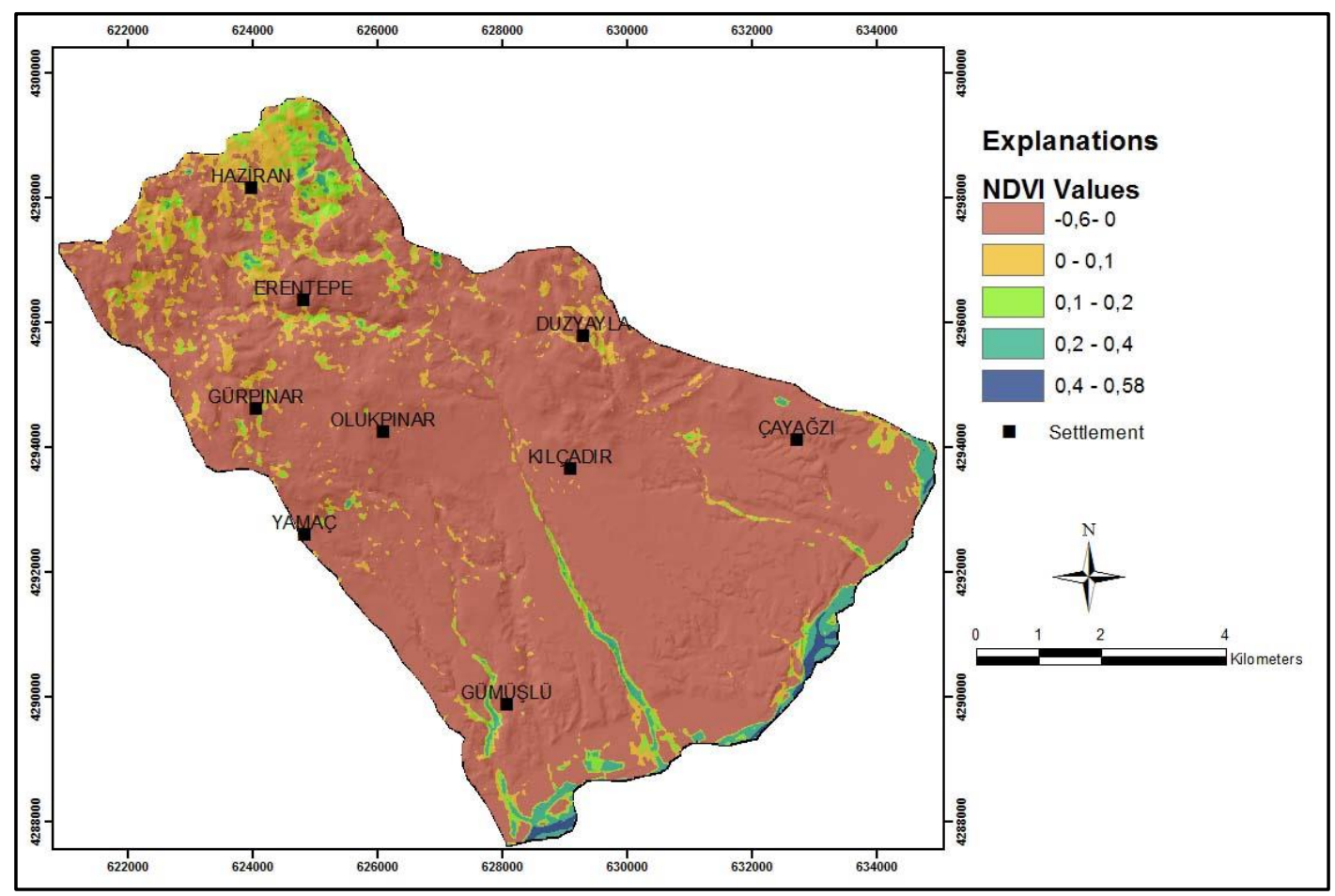

Figure 8. NDVI Map of Yamaç Basin (Bingöl)

This change in vegetation cover has had considerable effects on the appearance of landslides. Therefore, in order to reduce the effects of landslides, it is necessary to protect existing vegetation cover as well as afforestation works. 


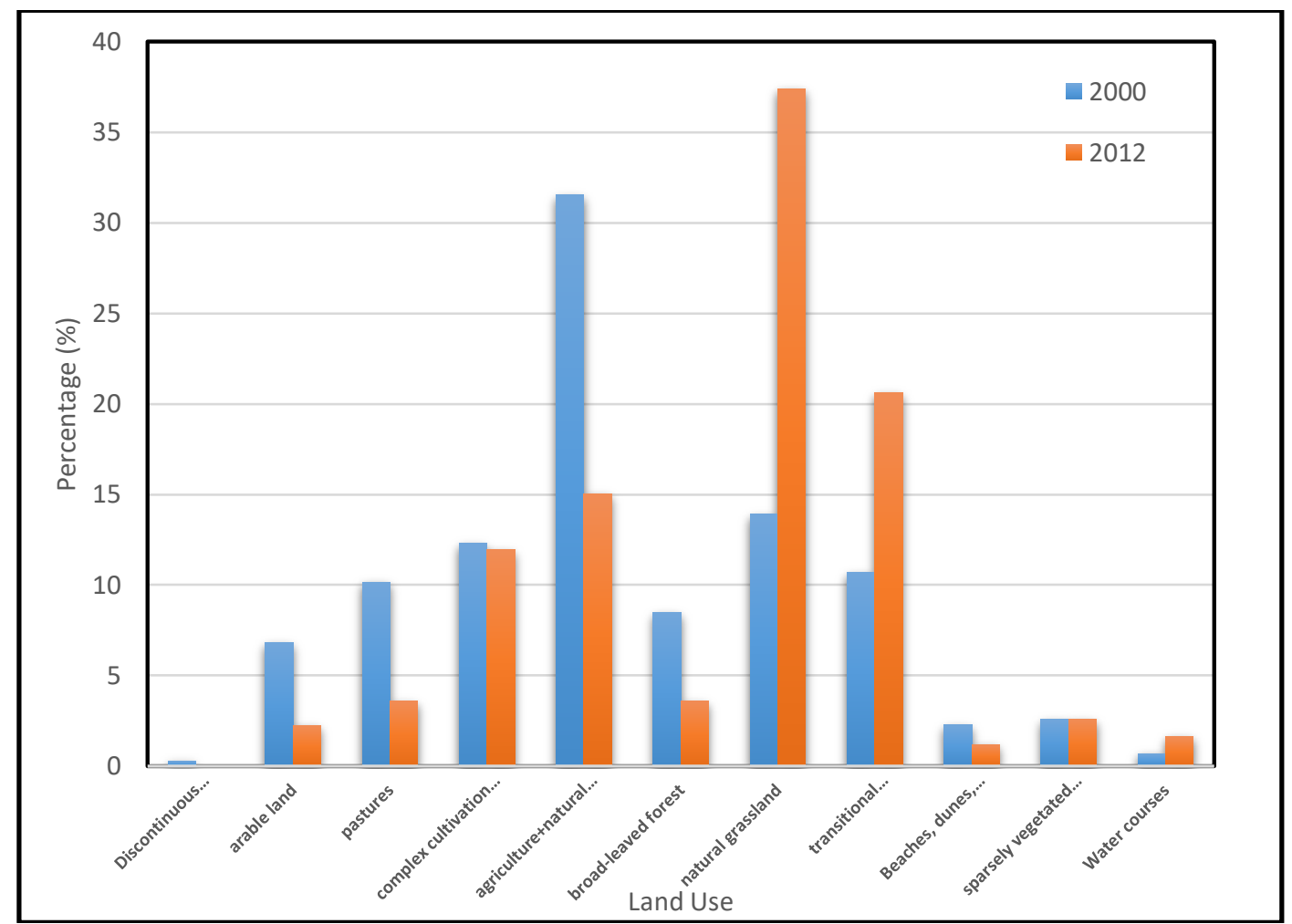

Figure 9. Proportional distribution of land use in 2000 and 2012 according to Corine data in Yamaç Basin

The Effect of Distance from River Systems on Landslides

The streams that constitute the drainage network have a negative impact on susceptibility, washing the slope buttress and saturating the part of the material that forms the slope below the stream (Ercanoğlu \& Gökçeoğlu 2004). This parameter has been used for susceptibility since the landslides in Yamaç Basin have occurred mostly near zones adjacent to streams. The zones far from streams between 0 and $100 \mathrm{~m}$ and 100 and $250 \mathrm{~m}$ cover a wide area, and most of the landslides have occurred between the groups of 0 to $100 \mathrm{~m}$ and 250 to $500 \mathrm{~m}$ (Fig. 10 , Table 2, Fig. 11). Although slopes of the valley are relatively rich in terms of vegetation, landslides are frequent. This situation is related to stream erosion and deterioration of slope balance. Because streams rise the slope- angle values by eroding the base of the streams, and disturb the balance of the upper level layers. 


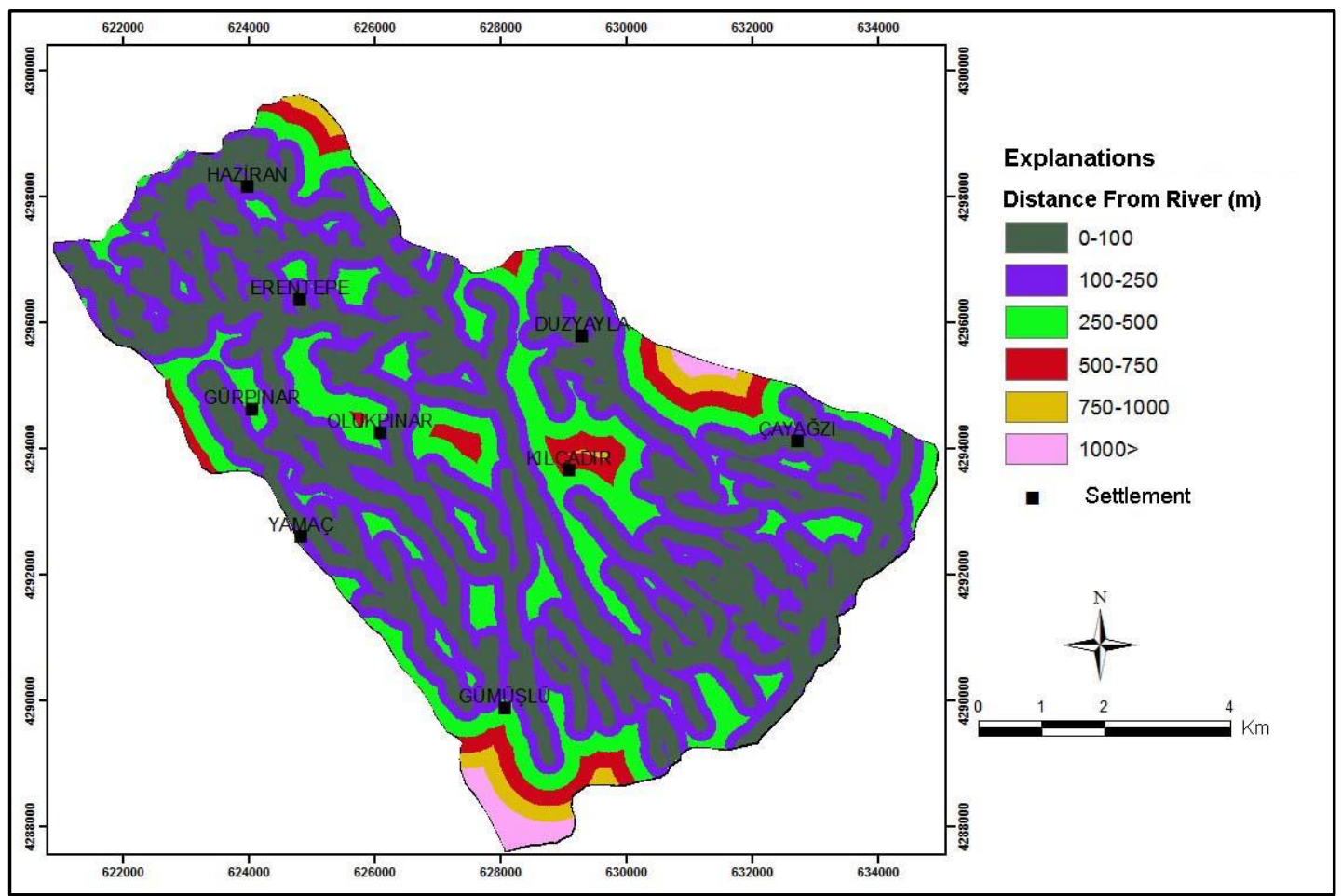

Figure 10. Map of the distance from river systems in Yamaç Basin (Bingöl)

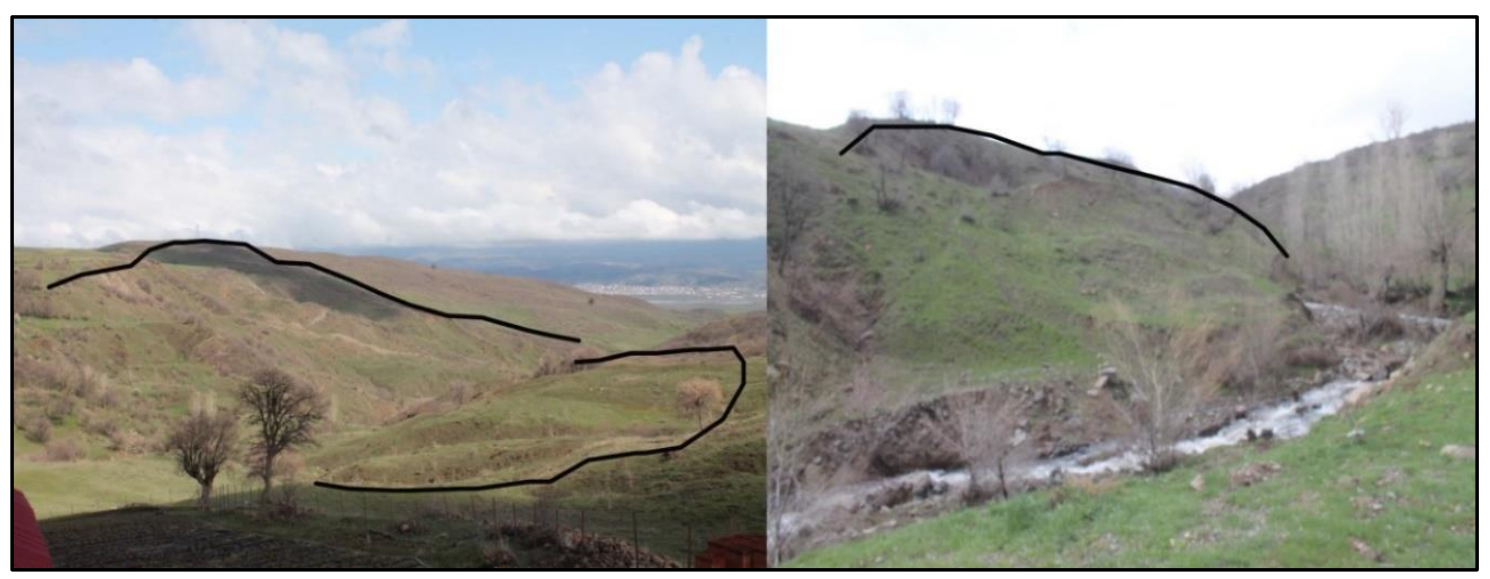

Figure 11. Landslides are seen in slopes of valley in Yamaç Basin

The Effect of Slope Curvature on Landslide

Curvature provides important information on the definition of landslides (Ermini et al, 2005; Gökçeoğlu \& Aksoy 1996). Since rotational slide-type landslides' surface of failure has a concave characteristic, the buttress area where the material accumulates has a convex profile. The middle area of these two parts, however, constitutes relatively plain areas and transition surfaces in the form of slightly convex surfaces. The total concave and convex slopes areas are higher than plain areas (Fig. 12). 


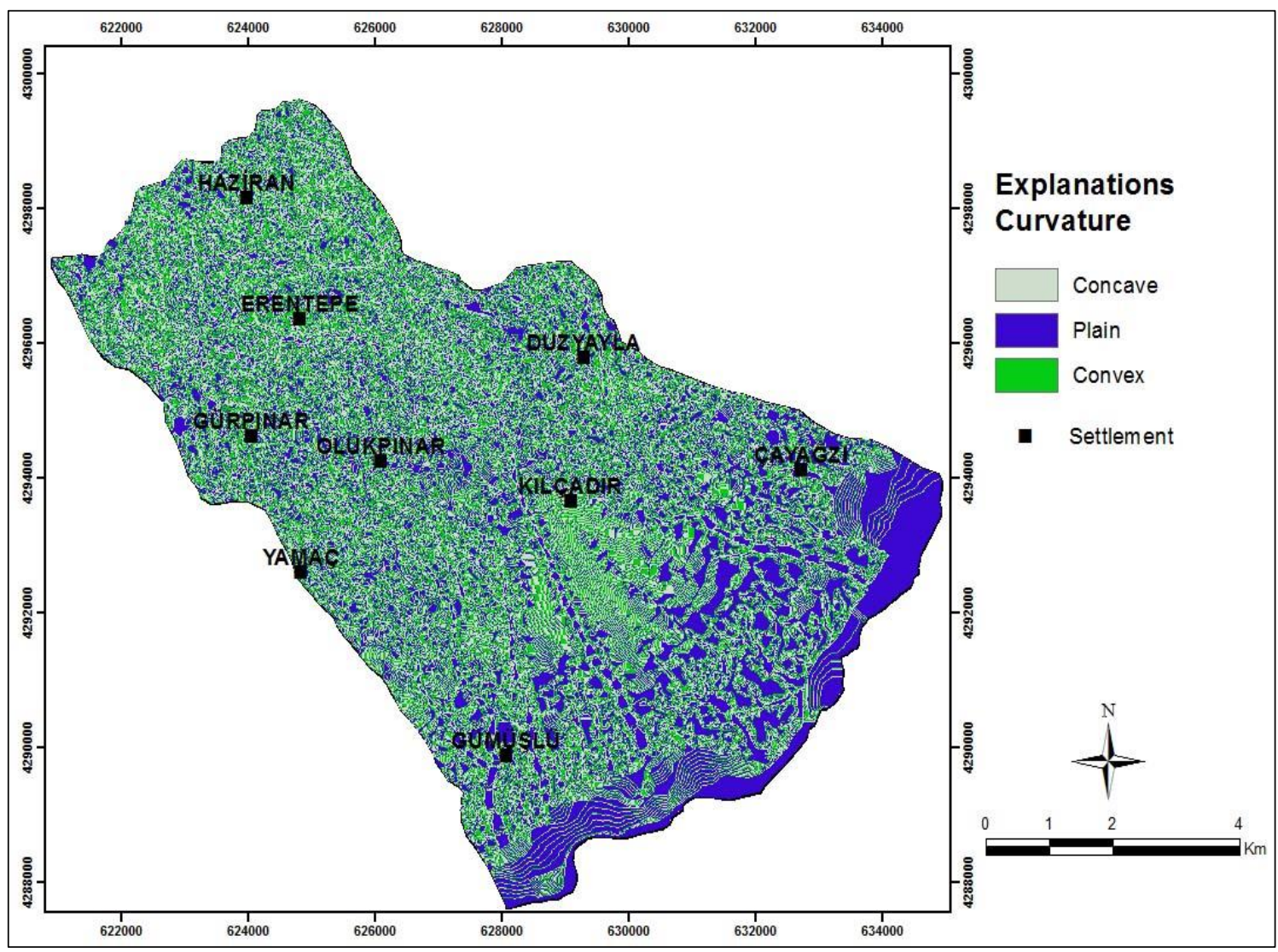

Figure 12. Map of slope curvature of Yamaç Basin

The concave and convex properties affect landslide formation by controlling the acceleration and deceleration of flow. Landslides are more common in convex slopes (Table 2).

\section{Conclusion and Suggestions}

According to the susceptibility map attained by using the index method through factors of lithology, aspect, slope, NDVI, distance to river networks and slope degree, zones having a very high susceptibility area account for $1 \%$, a high susceptibility area for $22 \%$, a moderate susceptibility area for $30 \%$, a low susceptibility area for $43 \%$ and a very low susceptibility area for $4 \%$ (Figure 13).

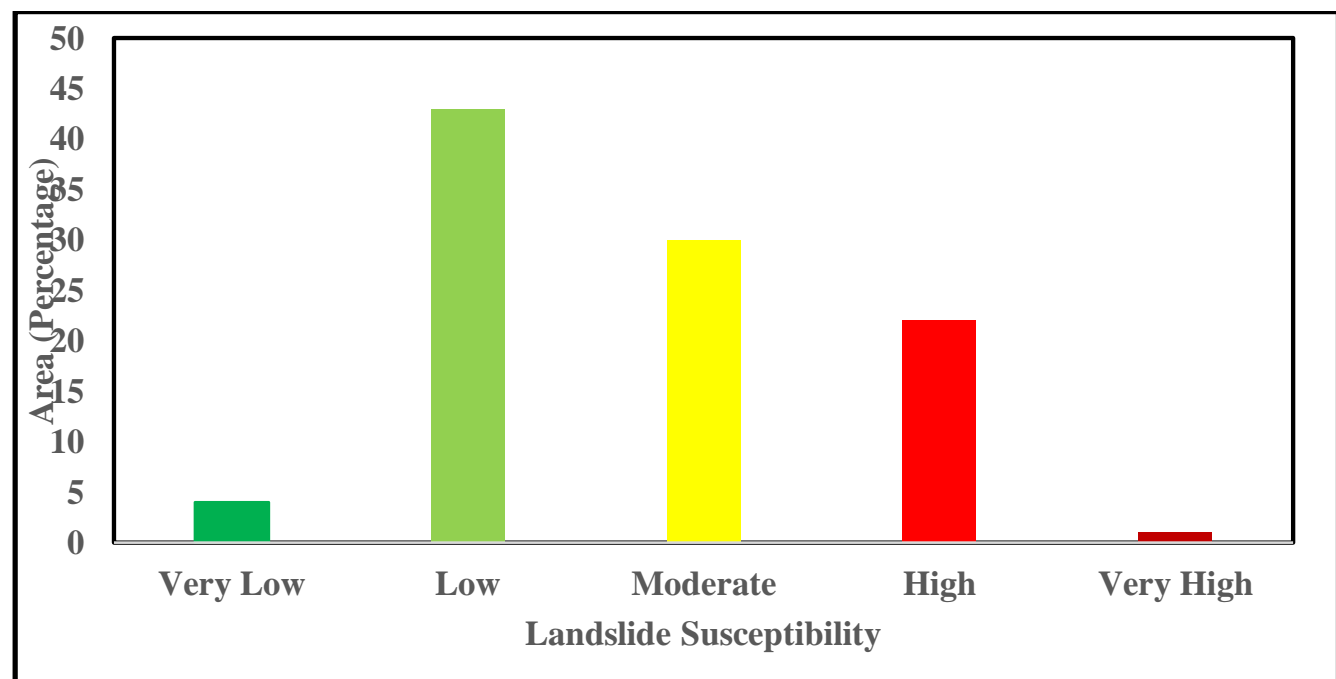

Figure 13. The distribution of landslide susceptibility in Yamaç Basin 
According to the susceptibility map significant differences were found between the northern and the southern parts of the basin in terms of landslide susceptibility. The northern zone has greater susceptibility than the southern zone (Figure 14).

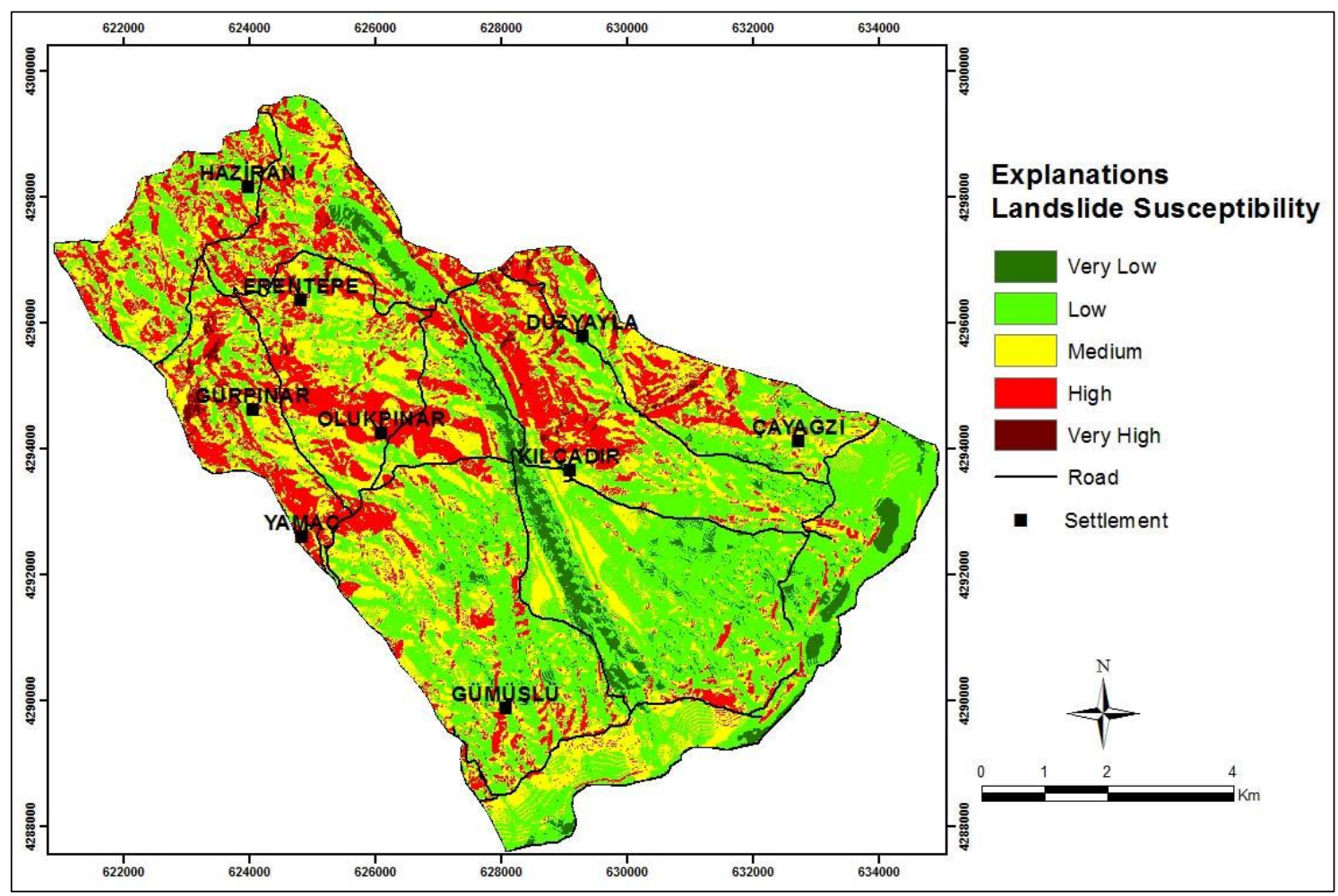

Figure 14. Landslide susceptibility map of Yamaç Basin

Distance to river networks, lithology, slope, aspect and had more effects on the susceptibility than the rest of the factors. Landslides center in the areas 250-500 m far from the streams. The high susceptibility of landslides on the valley slopes indicates the degree of the influence of the factor. Agglomerate and tuff landslides center in this lithology. Being saturated with streams and precipitation enable landslides in this lithology. Landslides occurred most frequently on the slopes having 7-25 and 1525 o angles. Landslides are very common on the south-facing slopes where precipitation and snow melt are very high, therefore, the landslide susceptibility is high. In the north, large landslides have occurred because the area has a clay structure formed by the dissociation of the surface tuff. The difference in the lithology between the north and the south of the basin can be seen in landslide susceptibility (Figure 14).

Slope is another important parameter for landslide susceptibility. The susceptibility generally increases as the slope degree increases. Another important factor is that landslides can be seen in even lower degree slopes, resulting from the lithology and the distance to river networks, and also due to higher precipitation and seismic activities.

The effect of this aspect on landslides is related especially to the precipitation on the south-facing slopes. Landslides increase in the north, where the slope degree of the mountains and slopes increases. Streams run deep due to high slope degrees, which cause massive landslide occurrences in the northern part of the basin.

The landslides damage the roads between Yamaç and Olukpınar villages in the north and between Erentepe and Haziran villages, where settlements are centered. The roads pass through mountains and basin slopes due to high slopes and unevenness in the north. Especially precipitation in the spring and higher snowmelt increase the number of harmful landslides in this area. 
Afforestation, drainage works due to high underground water level and landslide prevention facilities should be done to avoid landslides in the road of Yamaç and Olu1kpinar villages.

Animal husbandry is an important economic activity in the northern part of the basin. The meadows in the north are damaged by these landslides. Moreover, landslides occurring between Yamaç and Olukpınar may damage the agricultural lands.

Drainage works and oak afforestation suitable for the local climate should be done to refrain landslides in the cultivated areas located between Yamaç and Olukpinar villages.

In infrastructure works, the landslide susceptibility maps generated for Yamaç Basin could be used as a base. The susceptibility maps should be taken into consideration when roads are constructed.

The drift cracks has been occurred in the back vicinity of settlements in the north of the Yamaç village. Therefore, the Yamaç village should be listed as a landslide-watch.

Landslides cause important economic losses when the natural environment conditions are not considered during the construction of settlements, which is a very common practice in rural areas. To reduce the damage resulting from landslides, budgets should be allotted to planning projects, and the projects should be carried out painstakingly.

\section{References}

Ayalew, L., Yamagishi, H., Ugawa, N. (2004). Landslide susceptibility mapping using GIS-based weighted linear combination. The Case in Tsugawa Area of Agano River, Niigate Prefecture, Japan. Landslides (1), 73-81.

Ayalew, L., Yamagishi, H. (2005). The application of GIS-based logistic regression for landslide susceptibility mapping in the Kakuda-Yahiko Mountains, Central Japan. Geomorphology, (65/1-2), 15-31.

Baeza, C., Corominas, J. (2001). Assessment of shallow landslide susceptibility by means of multivariate statistical techniques. Earth Surf. Process and Landforms, (26), 1251-1263.

Bourenane, H., Bouhadad, Y., Guettouche, M. S., Braham, M. (2015). GIS based landslide susceptibility zonation using bivariate statistical and expert approaches in the city of Constantine (Northeast Algeria). Bull Eng Geol Environ, 74 (2), 337-355.

Bui, D. T., Lofman, O., Revhaug, I., Dick. O. (2011). Landslide susceptibility analysis in the Hoa Binh province of Vietnam using statistical index and logistic regression. Nat Hazards, 59, 1413-1444

Caniani, D., Pascale, S., Sdao F., Sole, A. (2008). Neural networks and landslide susceptibility: a case study of the urban area of Potenza. Natural Hazards, 45 (1).

Carrara, A., Cardinali, M., Detti, R., Guzzetti F., Pasqui V., Reichenbach P. (1991). GIS techniques and statistical models in evaluating. Earth Surface Processes and Landforms, 16.

Chen, W., Chai, H., Sun, X., Wang, Q., Ding, X., Hong, H. (2016). A GIS-based comparative study of frequency ratio, statistical index and weights-of-evidence models in landslide susceptibility mapping, Arab J Geosci, 9, 204.

Chi, K., Lee, K., Park, N. (2002). Landslide stability analysis and prediction modeling with landslide occurrences on KOMPSAT EOC imagery. Korean Journal of Remote Sensing, 18 (1), 1-12.

Cevik, E., Topal, T. (2003). GIS-based landslide susceptibility mapping for a problematic segment of the natural gas pipeline, Hendek (Turkey). Environ Geol, 44, 949-962.

Dai, F. C., Lee, C. F., Li, J., Xu, Z. W. (2001). Assessment of landslide suspectibility on the natural terrain of lantau Island, Hong Kong. Environmental Geology, 43 (3), 381-391.

Dai, F.C., Lee, C. F. (2002). Landslide characteristics and slope instability modeling using GIS, Lantau Island, Hong Kong. Geomorphology, 42, 65-87.

Donati, L., Turrini, M. C. (2002). An objective method to rank the importance of the factors pre disposing to landslides with the GIS methodology: Application to an area of the Apennines (Valnerina; 
Perugia, Italy). Engineering Geology, 63, 277-289.

Duman, T Y., Olgun, Ş, Çan T., Nefeslioğlu, H A., Hamzaçebi S., Elmaci H., Durmaz S., Çörekçioğlu Ş. (2009). 1/500000 Ölçekli Türkiye Heyelan Envanteri Haritas1 Erzurum Paftas1, Maden Tetkik Arama Enstitüsü Genel Müdürlüğ̈̈, Ankara.

Ercanoğlu, M., Gökçeoğlu, C. (2004). Use of fuzzy relations to produce landslide susceptibility map of a landslide prone area (West Black Sea Region, Turkey). Engineering Geology, 75, 229-250.

Ermini, L., Catani, F., Casagli, N. (2005). Arficial neural networks applied to lansdslide susceptibility assessment. Geomorphology, 66, 327-343.

Gökçeoğlu, C., Aksoy, H. (1996). Landslide susceptibility mapping of the slopes in the residuel soils of the Mengen Region (Turkey) by deterministic stability analyses and image processing techniques. Engineering Geology, 44, 147-161

Gómez, H., Kavzoglu, T. (2005). Assessment of shallow landslides susceptibility using artificial neural networks in Jabonosa river basin, Venezuela. Engineering Geology, 78, 11-27.

Guzzetti, F., Carrara, A., Cardinalli, M., Reichenbach, P. (1999). Landslide hazard evaluation: A review of current techniques and their application in a Multi-Scale Study, Central Italy. Geomorphology, 31, 181-216.

Lee, S., Ryu, J., Won, J., Park, H. (2004). Determination and application of the weight for landslide susceptibility mapping using an artificial neural network. Engineering Geology, 71-80.

Pourghasemi, H. R., Jirandeh, A. G., Pradhan, B., Xu, C., Gokceoglu, C. (2013). Landslide susceptibility mapping using support vector machine and GIS at the Golestan province, Iran. J Earth Syst Sci, 122 (2), 349-369.

Regmi, A. D., Devkota, K. C., Yoshida, K., Pradhan, B., Pourghasemi, H. R., Kumamoto, T., Akgun, A. (2014). Application of frequency ratio, statistical index, and weights-of-evidence models and their comparison in landslide susceptibility mapping in Central Nepal Himalaya. Arab J Geosci, 7 (2), 725-742.

Saha, A. K., Gupta, R. P., Arora, M. K. (2002). GIS-based landslide hazard zonation in the Bhagirathi (Ganga) Valley, Himalayas. Int. J. Remote Sensing, 23 (2), 357-369.

Sümengen, M. (2011). 1/100000 Ölçekli Türkiye Jeoloji Haritalar1, Elazığ K44 Paftas1. MTA Genel Müdürlüğ̈̈ Jeoloji Etütleri Dairesi, Ankara.

Tonbul, S. (1990a). Bingöl ovas1 ve çevresinin jeomorfolojisi ve gelişimi. Coğrafya Araştırmaları Dergisi, Ankara, 2 (2), 329-352.

Tonbul, S. (1990b). Bingöl Ovas1 ve çevresinin iklimi. Firat Üniversitesi Sosyal Bilimler Enstitüsü Dergisi, 4(1), 263-314.

OFDA/CRED. (2010). EM-DAT International Disaster Database-www.emdat.net-Universit'e Catholique de Louvain-Brussels-Belgium

Van Westen, C. J. (1993). Application of geographic information systems to landslide hazard zonation. ITC Publication no: 15. International Institute for Aerospace and Earth Resources Survey, Enschede, The Netherlands, 245.

Van Westen, C. J. (1997). Statistical landslide hazard analysis, ILWIS 2.1 for Windows Application Guide. Enschede: ITC Publication.

Wu, S., Shi, L., Wang, R., Tan, C., Hu, D., Mei, Y., Xu, R. (2001). Zonation of the landslide hazard in the forereservoir region of the three gorges project on the Yangtze River. Eng Geol, 59, 51-58.

Yalçın, A. (2007). Heyelan duyarlılık haritalarının üretilmesinde analitik hiyerarşi yönteminin ve CBS' nin Kullanımı. Selçuk Üniversitesi Mühendislik Mimarlık Fakültesi Dergisi, (23/23), 1-14.

Yalçın, A. (2008). GIS-based landslide susceptibility mapping using analytical hierarchy process and bivariate statistics in Ardesen (Turkey): comparison of results and confirmations. Catena $72,1-$ 12.

Yalçın, A., Reis, S., Aydınoğlu, A. C., Yomralığlu, T. A. (2011). GIS-based comparative study of frequency ratio, 
analytical Hierarchy process, "bivariate statistics and logistics regression methods for landslide susceptibility mapping in Trabzon NE Turkey. CATENA, 85, 274287.

Yin, K. L., Yan, T. Z. (1988). Statistical prediction model for slope instability of metamorphosed rocks. In: Proceedings of 5 th international symposium on landslides, Lausanne, Switzerland, 2, 1269-1272.

Zezere, J. L. (2002). Landslide susceptibility assessment considering landslide typology. A case study in area north of Lisbon (Portugal). Nat Hazards and Earth Syst Sci, 2, 73-82. 